\section{ACRL BOARD PAYS TRIBUTE TO LOUISE GILES}

At its first Midwinter meeting, the Board of Directors of the Association of College and Research Libraries paid the following tribute to Louise Giles.

Sadly, there comes a time when it is too late to commend a friend for a job well done. Such a time has come, and this is our tribute to Louise Giles.

Louise Giles was a fine administrator, a professionally dedicated librarian, a tireless and faithful worker in our association, a leader, an inspiration to beginning librarians, an innovator interested in improving library service, but most of all she was a warm, outgoing, and committed human being.

She was dean of learning resources at Macomb County Community College in Michigan, a former chairman of the Community and Junior College Libraries Section, a past president of the Association of College and Research Libraries, and an American Library Association councilor.

None of these accomplishments, however, adds up to what Louise Giles was to each of us, and that is, a friend. Therefore, let us remember her friendship and her spirit and rededicate ourselves to our communities and our association.

\title{
Stanford Authorizes New Library
}

Construction of a new $\$ 20$ million Main Library center at Stanford was authorized November 9 by the Stanford University Board of Trustees.

The center will consist of a new 180,000gross-square-foot structure added to the remodeled existing Main Library of 175,000 square feet.

Long regarded as Stanford's top priority building project, the new structure will house one million volumes in its general collections. Physically connected with the current Main Library, it will be flanked by the J. Henry Meyer Memorial Library and the Hoover Institution, creating a new "Library Quad" at the university.

More than $\$ 15$ million in gifts and pledges already has been received for the new center. The remainder will be sought during construction, which is expected to start in early 1977 and take nearly two years to complete.

President Richard W. Lyman reported an anonymous pledge of $\$ 6$ million toward the new library. Another $\$ 5$ million comes from an anonymous "challenge" pledge and gift to the university, with $\$ 2$ million from the James Irvine Foundation and $\$ 1$ million from the Kresge Foundation. Smaller gifts account for an additional $\$ 1.3$ million.

Buff-walled and red-roofed, the new library will have three stories above ground and one below. It will be physically interconnected with the existing Main Library at all levels, with an underground connection to the Meyer Library basement, which houses 400,000 volumes of the Main Library collections.

The new library will have about 200 studies.

The Main Library reached its capacity in 1975 when the university also passed the four million mark in its total book collections. The

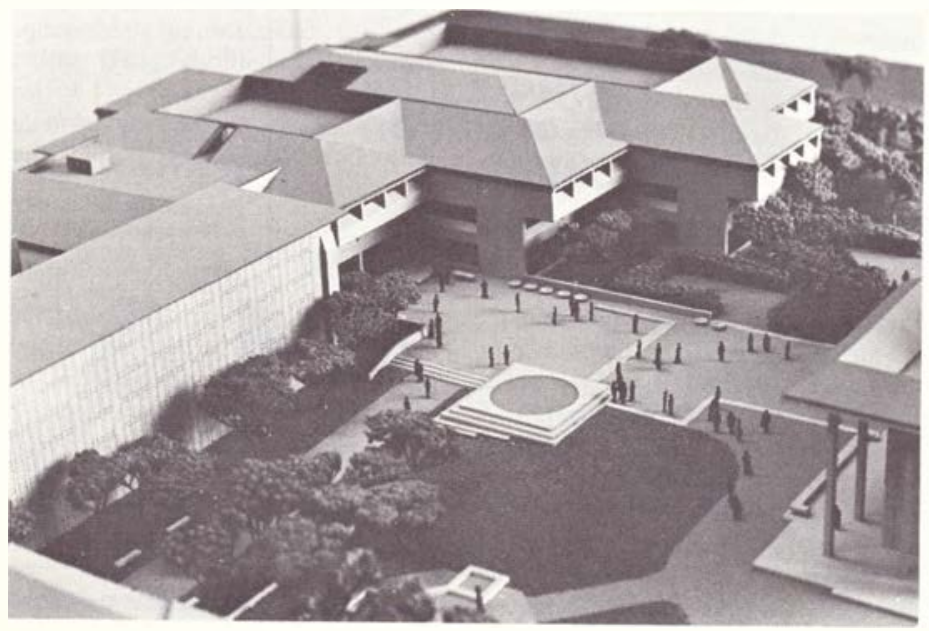


total system currently is growing by more than 100,000 volumes annually.

A leader in cooperative programs, the Stanford library system recently announced a joint program with University of California, Berkeley, designed to help curtail the growth rate in future acquisitions for the two institutions.

Project BALLOTS (Bibliographic Automation of Large Library Operations using a Timesharing System) has given Stanford the most comprehensive automated library system now in operation in academic institutions. Virtually all acquisition and cataloging activities are now automated, with consequent reductions in staffing and wider access for library users.

The new library will primarily house research collections in the humanities and social sciences.

"No university can be or remain great without a great research library," according to President Lyman. "Short of the coming of some new Dark Ages, one can be reasonably sure that the future of libraries will be shaped by the word 'more'-more kinds of materials, more kinds of users, more kinds of services, more kinds of relationships to other agencies, more dependence on advanced technology, more need for managerial and diplomatic skills of a very high order-the list is endless."

Stanford's existing Main Library was built in 1919 and designed to serve a university onefourth Stanford's current size. Schematic de- signs for the new structure were approved by the board of trustees in December 1975.

A spacious plaza will serve as a focal point for people coming to the Main Library Center and Meyer Memorial Library.

Architectural firm for the new building is Hellmuth, Obata, and Kassabaum, Inc., of San Francisco and St. Louis. Jeanne MacArthur is the project architect, while William Valentine and Gyo Obata were the principal and partner in charge of design, respectively.

믐

\section{Index Medicus Expands Coverage}

Beginning with the May 1976 issue, selected congresses, symposia, proceedings, and multi-authored monographs are being included in Index Medicus. A reference to nonjournal items includes the first author or editor, title, place of publication, publisher, date, and the NLM call number.

Due to the increased demand for this book material, the National Library of Medicine has restricted its circulation but is willing to copy up to three different chapters from one book provided there is only one chapter requested per interlibrary loan and the chapter does not exceed 50 pages.

\section{Have you subscribed yet?}

\section{British \\ Humanities Index}

Annual subscription $\$ 82.50$

\section{British \\ Technology Index}

Annual subscription $\$ 168.00$

\section{Journal of Librarianship}

Annual subscription $\$ 20.00$

\section{Library and Information Science Abstracts}

Annual subscription $\$ 72.50$

\section{Library Association Record}

Annual subscription $\$ 25.00$ (Free to LA members)

\section{Radials Bulletin}

(Research and development Information \& Library Science) Annual subscription $\$ 25.00$

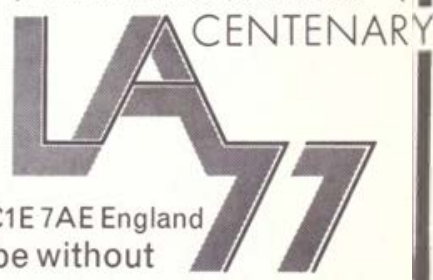

